\title{
Bangladesh's Claim for Reparation from Myanmar due to Rohingya Influx: Options and Challenges
}

\author{
https://doi.org/10.21272/sec.4(1).65-74.2020
}

Md. Ayub Ali, ORCID ID: https://orcid.org/0000-0002-5362-0858

LL.M., DU, Assistant Professor, Department of Law \& Justice, Southeast University, Bangladesh

\begin{abstract}
The article summarizes the arguments and counterarguments within the scientific debate on the application of the principles and practices of international law to assess the compensation of a State's damage as a result of the illegal acts and / or inaction of another State. The main purpose of the study is to analyze the causes of the crisis against the Rohingya ethnic group and to assess its likely devastating effects on Bangladesh. The systematization of literary sources and approaches to the settlement of international disputes of this kind indicate that in practice there are two approaches that can be used to file and pursue a claim for redress for Myanmar. The urgency of solving this scientific problem is that, as a neighboring country, Bangladesh has faced the need to resolve the issue of refugees from the region and accordingly takes an active part in resolving this protracted conflict caused by Myanmar's actions against the Rohingya ethnic group, the persecuted ethnic minority in the world. According to the Office of the United Nations High Commissioner for Refugees, the unlawful and brutal actions of the Myanmar army have forced more than a million Rohingya refugees to flee their homes and migrate to Bangladesh, causing enormous negative effects on its economy, the environment and the rule of law. The study confirms that, under international law, Bangladesh has the right to sue Myanmar for unfair and cruel oppression of Rohingya rights. During the course of the study, the author has used such sources as periodicals, UN reports and documents from Rohingya human rights organizations. The principles of international law on state liability are used as a methodological tool for assessing Myanmar's liability. The results of the study may be useful for policymakers exploring the strategy of addressing the challenges of Myanmar's compensation claims, as well as for international organizations that are addressing the Rohingya crisis.
\end{abstract}

Keywords: cruelty, international wrongdoing, imperative norm, compensation, state responsibility, Myanmar, Bangladesh, Rohingya national migration, refugee rights, ethnic minorities, damages lawsuit.

JEL Classification: K33.

This work is licensed under a Creative Commons Attribution 4.0 International License.

Cite as: Ali, Md. Ayub (2020). Bangladesh's Claim for Reparation from Myanmar due to Rohingya Influx: Options and Challenges. SocioEconomic Challenges, 3(4), 65-74. https://doi.org/10.21272/sec.4(1).65$\underline{74.2020}$.

(C) The Author, 2020. This article is published with open access at Sumy State University.

\section{Introduction}

The Rohingya refugee crisis is one of the complex issues the present world is currently facing. Having commenced in the middle of the $18^{\text {th }}$ century with the Burmese invasion of the ancient Arakan, the problem has taken a serious turn in 2017 leaving thousands of Rohingya families in Rakhine landless and homeless. The step-motherly and hostile attitude of the military backed autocratic government of Myanmar towards the Rohingyas is mainly responsible for such humanitarian disaster. The people who have been living in Arakan, the present day Rakhine state, maintaining roots and family bondage through their ancestors with the soil, have been rendered stateless with the enactment of the disputed Citizenship Act in 1982. Taking stand against international obligation, Myanmar is adopting the persecution, genocide and other crimes as the means to deport or eliminate the Rohingya people from the country. The UN Fact Finding Committee reported that it found the elements of genocide committed on Rohingya community since 2017 in Myanmar. Such kinds of large-scale human rights abuses and heinous crimes are the flagrant violation of international law posing prejudice to the interest of the neighbouring countries. Bangladesh is the direct victim as a result of the 
Rohingya crisis in Myanmar as it shares a 170 mile long border with Myanmar where in Myanmar side, 80 percent of the population is Rohingya. As of 2018, more than 1 million Rohingyas crossed over from Myanmar to Bangladesh mounting burden on the economy, environment as well as creating menace to the territorial integrity and law and order of Bangladesh. According to international law, Myanmar bears the state responsibility for causing harm to Bangladesh through its acts or omission. This is the cardinal principle of international law that every violation of law generates an automatic obligation on the wrongdoing state to remedy the breach.

\section{Literature Review}

The Rohingya are a Muslim ethnic group residing in the Buthidaung and Maungdaw Town ships of the northwestern part of the Arakan State, Burma. They live here as the majority together with the Buddhist Arakanese and Burmese (Smith, 1991.). Now-a-days, Rohingya community is the most persecuted one in the world. Though the Rohingya minority group has been living in Rakhine State for ages, they have apparently been stateless since the military government passed the 1982 Citizenship Act denying their equal access to citizenship (BROUK, 2014). The genesis of Rohingya problem may be traced in the conquest of Arakan in 1785 by the Konbaung Dynasty which compelled as many as 35,000 people of the Rakhine state to flee to the neighbouring Chittagong region of British Bengal in 1799 to escape persecution to seek protection under the British Raj (Chan, 2005). It triggered a long guerrilla war in which the Burmese army allegedly killed more than 200,000 Arakanese (Ahmed, 2010). This resulted in the exodus of almost two-thirds of the Muslim Arakanese population into the Chittagong area, today's Cox's Bazar in Bangladesh. When the British incorporated Arakan and the rest of Burma into its empire by 1885, many refugees returned to Arakan (New Mandala, 2014). During the Japanese occupation, the Rohingyas expressed loyalty to the British (Slim, 2009) and claimed autonomy in the northern part of the state which was viewed by the Burmese administration as betrayal and territorial undermining, fueling their attitude of suspicion and estrangement toward the Rohingyas that lingers today.

In the independent Burma, the Rohingya community was recognized as an indigenous ethnic nationality and a number of Rohingya people were elected as the representatives in the Burmese parliament as well as held the very prestigious position in the government like ministers, parliamentary secretaries (Radio Free Asia, 2010).But since Burma's military junta took control of the country in 1962, the Rohingya have been systematically deprived of their political rights.

The 1974 Emergency Immigration Act stripped the Rohingyas of their nationality, rendering them foreigners in their own land. The denial of citizenship inarguably remains the root cause of the Rohingyas' endless cycle of forced migration. In 1977, the Burmese military government launched an operation to register the citizens and prosecute the illegal entrants. The nation-wide campaign started in Rakhine State, and the mass arrests and persecution, accompanied by violence and brute force, triggered an exodus in 1978 of approximately 200,000 Rohingyas into Bangladesh (Abrar, 2010). Within 16 months of their arrival, most were forced back after bilateral agreements were made between the governments of Burma and Bangladesh. Since theArakan Rohingya Salvation Army (ARSA) attacks on 25 August 2017, more than ten lakhs of Rohingya have been taking shelter in Bangladesh

The movement of hundreds of thousands of Rohingya into Bangladesh in a short period, driven by the cruel, sadistic Myanmar army, is causing grave damage to Bangladesh (Cookson, 2017). The Rohingya refugees are generating conflict, dilemma, and insecurity in their host country, Bangladesh (Rahman, 2010). As such, the Rohingya crisis is no longer only a humanitarian calamity but a potential threat to Bangladesh's internal stability. As the huge influx of Rohingya is the aftermath of a premeditated ethnic cleansing carefully designed by the Myanmar government, the author draws the following hypothesis:

i. That Myanmar has committed internationally wrongful acts and as such incurs state responsibility towards Bangladesh for damages caused to it; and

ii. That Bangladesh as a host country is entitled to raise a claim of reparation to and against Myanmar for creating the Rohingya refugee crisis.

The Rohingya crisis between Bangladesh and Myanmar is almost identical with the Palestinian refugee problem that arose between Israel and Jordan as a result of Arab-Israel wars of 1949 and 1967. Bisher Hani Khasawneh (2007) examined the right of Jordan as a host country, under international law, to bring 
compensation claims to and against Israel for creating the Palestinian refugee problem. In her thesis, the author scrutinised the legal bases for such a right, under international law in the context of State Responsibility for wrongful acts along with the procedures and mechanisms available for the pursuit of such claims.

\section{Methodology}

This is a doctrinal research based on qualitative approach. The research materials consist of both primary and secondary sources. An extensive review of literature has been conducted in order to establish a conceptual framework. The author has examined existing scholarships, newspaper articles, UN reports and Human Rights Organisations' reports on the Rohingya. The researcher has applied principles of international law with regard to state responsibility for internationally wrongful acts as set out in ILC's Draft Articles (ILC, 2001) and in judicial precedents to determine whether Bangladesh is entitled to raise a claim of reparation against Myanmar for Rohingya influx.

\section{Atrocities Committed on Rohingyas}

The Rohingya are the most persecuted and abused minorities in the earth only owing to their ethnicity and religious ground (OUN, 2012). The atrocities on Rohingyas in Rakhine state has been termed by the United Nations as 'the text book example of ethnic cleansing' (Guardian, 2017).The brutal security operation of Myanmer security forces against the Rohingya in Rakhine state is clearly disproportionate, unjust and indiscriminate. The Patterns of violations committed by Myanmar military and security force include conduct of hostilities in flagrant disregard of civilian life and property, unlawful killings, torture and other ill treatments, sexual and gender based violence, arbitrary deprivation of liberty and enforced disappearance, forced labour and forced recruitment of adults and children, forced displacement, confiscation and destruction of property, and denial of humanitarian assistance (HRC, 2018). Besides, crimes under international law like genocide, crimes against humanity and war crimes have been committed on Rohingya community (HRC, 2018). Because of intolerable persecution, thousands of Rohingya fled into Bangladesh in 1784, 1942, 1978, 1991-192, 2012 and 2017. They flowed from Myanmar to Bangladesh for the ethnic and religious conflicts over the centuries (HRW, 2000).

\section{Impact of Rohingya Problem on Bangladesh}

Considering the humanitarian grounds, Bangladesh has extended all-out assistance towards the Rohingya driven by the cruel, sadistic Myanmar army and is providing them with the protection and other provisions of life. But the huge inflow of Rohingya is causing grave damage to Bangladesh by exerting the huge negative impact on its economy and environment particularly, the effect on the southern part of Bangladesh along the border with Myanmar is devastating.

Though the government took initiative to register the Rohingya refugees and keep then within the temporary camps, most of them still remain undocumented posing a serious threat to the security, stability and image of the country through their involvement in serious crimes including drug and human trafficking, smuggling, robbery and other organized crimes. These illegal Myanmar nationals are obtaining Bangladeshi passports to go to Saudi Arabia and other states in the Middle East through fraudulent means, falsification of national ID cards and birth certificates which are causing huge embarrassment for the Bangladesh community living in those states (Islam, 2012).

The massive number of rohingya refugees is straining Bangladesh in five ways namely political impact, security challenges, economic effects, social strains and environmental destruction (Alam, 2018). According to a study by Centre for Policy Dialogue (CPD, 2018), the Rohingya crisis is putting an adverse effect on Bangladesh, mostly on the country's economy, society and the environment. Economic impact includes pressure on employment, depression of daily wage and cost of living; the social impact includes loss of school years for locals, health issues among Rohingyas and locals (mortality and morbidity, chronic malnutrition, respiratory illnesses, etc.). Environmental effects are deforestation, loss of biodiversity and ecosystem, and natural calamities like landslides.

Around 6,000 acres of land has been deforested by the Rohingya camps which is equivalent to Tk. 741.3 crore or USD 86.7 million (CPD, 2018).Beginning from 25 August 2017 till 25 March 2018, \$322 million have been donated for the Rohingyas through international donor agencies. The Bangladesh government has estimated that $\$ 434$ million has been spent on some 80 million Rohingyas till then. And $74 \%$ of that expense 
has been borne by the agencies, but the rest have been accumulated by our government (CPD, 2018). Based on the above expenses, it has been estimated that the fund requirement for hosting the Rohingyas for the period of Fiscal Year 2018-2019 would be about USD 951 million (CPD, 2018).

Table 1. Estimation of requirements by the UNHCR and the CPD

\begin{tabular}{|c|c|c|c|c|c|c|}
\hline \multirow{2}{*}{$\begin{array}{c}\text { UNHCR } \\
\begin{array}{c}\text { Estimation for } \\
\text { Mar-Dec 2018 } \\
\text { (MillionUSD) }\end{array}\end{array} \quad \begin{array}{c}\text { CPD's Estimation for FY19 } \\
\text { (Based on UNHCR Estimation) }\end{array}$} & \multicolumn{3}{|c|}{ Cost as Percentage Share of } \\
\cline { 2 - 7 } & (Million USD) & (Crore Tk.) & $\begin{array}{c}\text { National } \\
\text { Budget FY18 }\end{array}$ & $\begin{array}{c}\text { GDP } \\
\text { FY18 }\end{array}$ & $\begin{array}{c}\text { Total Revenue } \\
\text { for Bangladesh } \\
\text { FY18 }\end{array}$ & $\begin{array}{c}\text { Social Protection } \\
\text { and Empowerment } \\
\text { Allocation FY18 }\end{array}$ \\
\hline 950.80 & 1211.00 & 100973.18 & 2.47 & 0.42 & 3.44 & 17.99 \\
\hline
\end{tabular}

Source: UNHCR (2017); CPD (2018).

The huge numbers of Myanmar nationals are adding extra pressure on the existing crisis of the land and forests in the Bandarban and Cox's Bazar areas. Bangladesh has lost considerable area of reserve forest for providing land to the refugees for construction of their shelter (Haque, 2012). The Rohingya are cutting off valuable trees and destroying woods in the reserve forests in the Bandarban and Cox's Bazar areas causing serious harm to environment and bio-diversity.

A bilateral agreement was solemnized between Bangladesh and Myanmar on 23 November 2018 to repatriate hundreds of thousands of Rohingyas who are sheltered in Cox's Bazar. However, not a single person was taken back due to the unwillingness of Myanmar (Bhuiyan, 2019). As such the burden of hosting the large number of refugees is mounting on Bangladesh. The Center for Policy Dialogue (CPD) has drawn a hypothesis where it has been estimated the cost of hosting this large number of Rohingya in case no initiative is taken for repatriation in next 1-, 5-, 10- and 12 years.

Table 2. Cost of hosting Rohingyas in 1-, 5-, 10- and 12-year periods if there is no repatriation

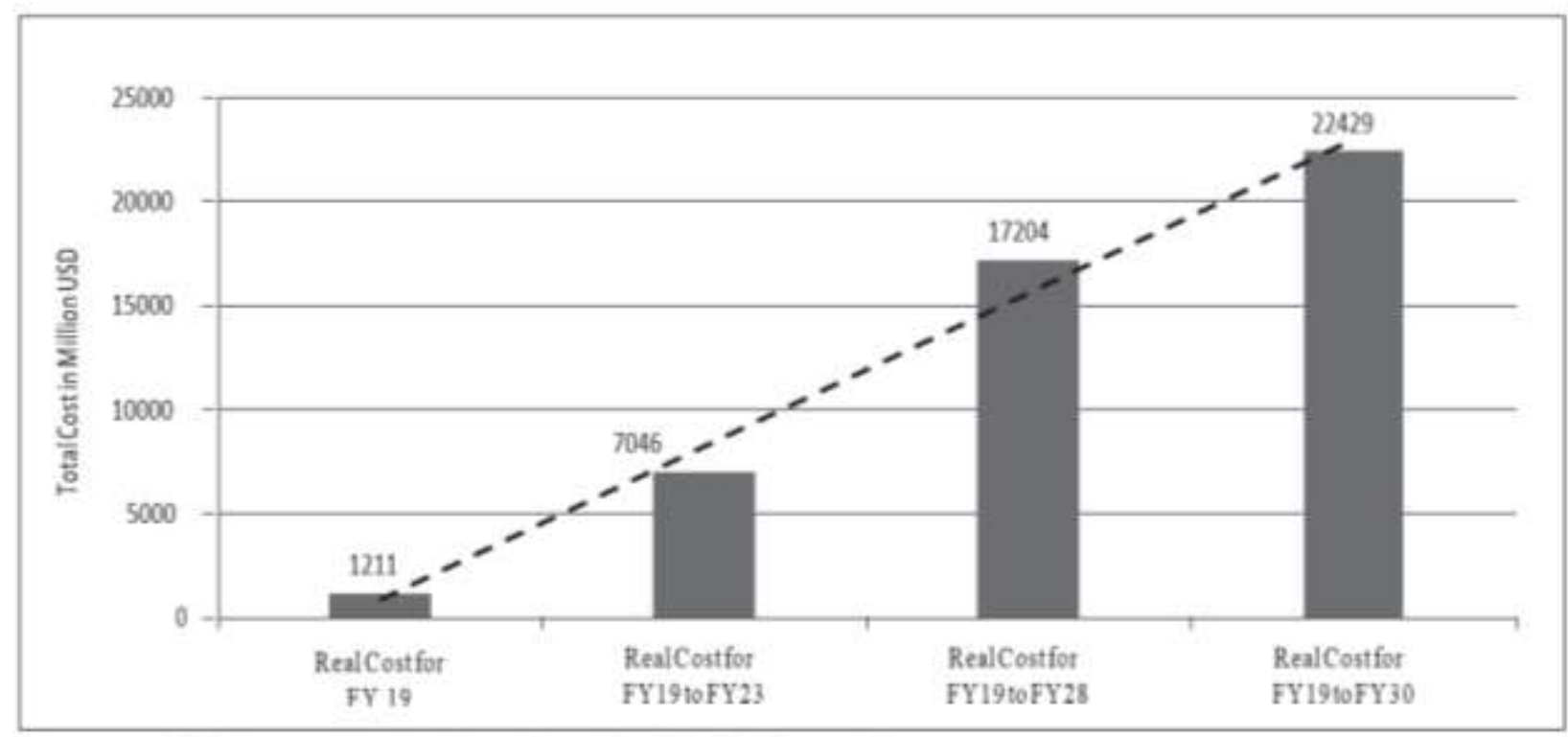

Source: CPD's calculation based on the UNHCR (2017).

\section{Liability of Myanmar under Int'l Law}

As a member of the United Nations, Myanmar is responsible to respect the norms and principles of the UN Charter to reaffirm faith in fundamental human rights, equality or non discrimination, dignity and worth of the human being. Though Myanmar is not the party to major human rights treaties, it is the signatory state to the United Nations Child Rights Convention (UNCRC), the Convention on the Elimination of All forms of Discrimination against Women (CEDAW) and the Four Geneva Conventions. Very recently, it ratified the International Covenant on Economic, Social and Cultural Rights (ICESCR) in 2017. 
Myanmar is under obligation to ensure the protection of civilian persons in times of war which it absolutely failed. In accordance with the UNCRC, the children shall be registered immediately after birth acquiring nationality and the states Parties shall ensure the implementation of certain rights in accordance with their national and relevant international laws for the protection of refugees, stateless and displaced children.Burma's military government ratified the CEDAW in 1997. The Convention obliges signatory governments not only to promote and protect women's human rights through appropriate programs in the public sphere, but also to eliminate discrimination and work to change gender stereotypes that disadvantage women (Brenda, 2012). According to Article 15 of the Universal Declaration of Human Rights (UDHR), 1948 everyone has the right to nationality and no one shall be arbitrarily deprived of his nationality nor be denied to change the nationality. But for ages, Myanmar has been showing disrespect to human rights of its citizen and thereby became the perpetrator of human rights violation. Large-scale violation of human rights in Rakhaine state of Myanmar is evident from a report of United Nations Office of the High Commissioner for Human Rights (UNOHCHR). The UN Fact Finding Mission described the violation as "widespread and systematic attack on [civilians]" including "murder, imprisonment, enforced disappearance, torture, rape, sexual slavery and other forms of sexual violence, persecution, and enslavement" with "elements of extermination and deportation" as well as "systematic oppression and discrimination [that] may also amount to the crime of apartheid" (JRP, 2019).

As such, Myanmar has violated its international obligations enunciated from Charter of the United Nations, Universal Declaration of Human Rights (UDHR), International Covenant on Economic, Social and Cultural Rights (ICESCR), International Covenant on Civil and Political Rights (ICCPR), Convention on the Rights of Children (CRC) and other customary principles of international law. Myanmar is not a party to UDHR and ICCPR but it has obligation to carry out the basic principles enshrined in these covenants inasmuch as the provisions of UDHR and ICCPR have gained the status of jus cogens due to recurrent practice of the states.

The question of state responsibility arises when a state violates any legal obligation under international law and as such, causes damage to another state. In Dickson Car Wheel Company (U.S.A.) v. United Mexican States (1951), it was held that any violation by a state of any obligation, of whatever origin, gives rise to state responsibility. Arbitrator Max Huber observed in International Fisheries Company (U.S.A.) v. United Mexican States (1931), that responsibility is the necessary corollary of rights and all international rights entail international responsibility. The rules of state responsibility determine when an obligation has been breached and the nature of legal consequences of that violation (Garcia and Garza v. USA, 1926). Following elements constitute state responsibility (Rahman, 2005): (a) there exist legal obligations under international law; (b) such obligation(s) has been violated by an act or omission of the state; (c) such act or omission is directly attributed to the state; and (d) other states suffer certain damages for such act or omission. Therefore, through violation of obligation to protect its own citizen, Myanmar has committed internationally wrongful acts.

Generally, breach of international obligations by a state is called internationally wrongful acts and the violating state is held responsible to give compensation to the state(s) which sustain injury or damage due to such breach of international obligations. The rules of state responsibility determine when an obligation has been breached and the nature of legal consequences of that violation. For instance, if a state suffers damage for violating by another state the rules of international law with respect to the use of armed force, the questions as to the responsibility for internationally wrongful acts will arise.

According to ILC Draft Articles (2001), internationally wrongful act means a conduct constituted an action or omission which violates an international obligation, and is attributable to a state under international law. This definition provides two elements for considering an action or omission to be an internationally wrongful act: (a) this act must be attributable to the state under international law; and (b) it must constitute a breach of an international obligation.

In Tehran case (1980), it was pointed out that in order to establish the responsibility of the Islamic Republic of Iran, first, it must determine how far, legally, the acts in question may be regarded as imputable to the Iranian state; and secondly, it must consider their compatibility or incompatibility with the obligations of Iran under treaties in force or under any other rules of international law that may be applicable. The atrocities committed by the security forces of Myanmar are directly attributed or imputed to Myanmar as Myanmar, instead of taking preventative measures, patronized through acts or omission the commission of such heinous crimes on Rohingya community. 
The general rule is that the only conduct attributed to the State at the international level is that of its organs of government, or of others who have acted under the direction, instigation or control of those organs (Brownlie, 1983). Article 8 deals with two such circumstances (ILC Draft Articles, 2001).Firstly, private persons acting on the instructions of the State in carrying out the wrongful conduct; and secondly, private persons acting under the State's direction or control. It is clear that a State may, either by specific directions or by exercising control over a group, in effect assume responsibility for their conduct. Each case will depend on its own facts. In the text of article 8, the three terms "instructions", "direction" and "control" are disjunctive; it is sufficient to establish any one of them (Commentaries, ILC Draft Articles, 2001). Regarding the degree of control, it was held by the ICJ in Nicaragua case (ICJ, 1986) that the United States was responsible for the "planning, direction and support" given by the United States to Nicaraguan operatives. In the Tadic case (ICTY, 1999), it was held that the requirement of international law for the attribution to States of acts performed by private individuals is that the State exercises control over the individuals. The degree of control may, however, vary according to the factual circumstances of each case.

The armed force and other security forces of Myanmar and some extremist Buddhist Monks and local inhabitants are involved in different crimes against the Rohingya minority and therefore, these activities are attributed to Myanmar as the UN fact-finding mission on Myanmar reports:

"The mission established consistent patterns of serious human rights violations and abuses in Kachin, Rakhine and Shan States, in addition to serious violations of international humanitarian law. These are principally committed by the Myanmar security forces, particularly the military. Their operations are based on policies, tactics and conduct..." (UNHRC, 2018).

In this case, Myanmar's responsibility is both subjective and objective. The 'objective or risk' theory is based upon the principle of objective responsibility which maintains that the liability of the State is strict. Once a wrongful act causing damage has been committed by a State official or organ, that State will be responsible under International Law to the injured State irrespective of its intention (LLP, 2013). Thisresponsibility is based on the doctrine of the voluntary act provided that agency and causal connection are established, if there is breach of duty by result alone (Brownlie, 2002). In Neer Claim (1926), the President of Claims Commission applied the doctrine of objective responsibility of the state. On the other hand, the 'subjective or fault' theory provides that a state's responsibility is essentially delictual and based on fault requiring either intentional or negligent conduct on the part of the state before a breach by it of an international obligation can be established (Starke, 1989). It requires the establishment of an element of intention, fault or negligence on the part of the State official or organ before rendering the State liable for any damage.

The aforesaid discussion made it conspicuous that Myanmar is responsible for the much influx of the Rohingya which is causing huge damage to the economy, environment and law and order situation of Bangladesh. Because the Rohingya crisis is created by Myanmarby adopting discriminatory policy regarding the status of Rohingya community and consequently the failure or omission on the part of Myanmar authority to perform its obligation under international law to protect its own citizen amounts to internationally wrongful acts.

\section{Options for Bangladesh to Claim Reparation}

Reparation in international law means the process and result of remedying the damage or harm caused by an unlawful or wrongful act. In international law, a breach of an international obligation gives rise to a duty to repair the harm caused. The state responsible for an internationally wrongful act is under the obligation to make full reparation for the injury caused by it (ILC Draft Article, 2001).Articles 35 to 37 elaborate upon the forms of reparation: (i) restitution (ii) compensation and (iii) satisfaction (ILC Draft Article, 2001). As a victim to the internationally wrongful acts committed by Myanmar, Bangladesh may avail of the following options to redress the damages.

Involve Int'l Community in repatriating the Rohingyas:

The problem lies in Myanmar, and the solution will also have to come from Myanmar (UNHCR, 2019). However, Myanmar, since the beginning of the problem, seems to be reluctant to initiate the process of repatriation and reintegration. Amid global criticism, Myanmar signed a repatriation deal with Bangladesh in 2018. The repatriation was supposed to start on January 23, but was delayed apparently for procedural issues. The Myanmar authority has done nothing to create conditions for safe and dignified returns or to address root 
causes of the crisis, including statelessness, impunity for grave violations by the military and recognizing Rohingya ethnicity.

What Bangladesh should do is to create international pressure on Myanmar for repatriating the Rohingyas. The United Nations particularly the UN High Commissioner for Refugees should be engaged with the process of repatriation. The role of UN is very crucial with regard to monitoring the situation in Myanmar. The international community should extend their support in ensuring the safe, dignified and sustainable return of Rohingya refugees from camps in Bangladesh.This support may include actions such as sharing information with the Rohingya on conditions in Myanmar so that they can make an informed decision. TheUN Security Council may play a vital role in this regard especially it can persuade Myanmar in taking initiative to implement the recommendations of the Rakhine Advisory Commission.

\section{Claim for Reparation from Myanmar:}

In addition to repatriation of the ten million Rohingya, Bangladesh may claim compensation from Myanmar due to the damage caused on its economy, society and natural resources.It was held in Chorzow Factory case by Permanent Court of International Justice (PCIJ) that every violation of law generates an automatic obligation on the wrongdoing state to remedy the breach (PCIJ, 1928). It is a principle of international law that the breach of an engagement involves an obligation to make reparation in an adequate form. Reparation therefore is the indispensable complement of a failure to apply a convention and there is no necessity for this to be stated in the convention itself. The responsible state is under an obligation to make full reparation for the injury caused by its internationally wrongful acts (ILC Draft Articles, 2001).In Ticona Estrada and Others v. Bolivia (IACHR, 2008), it was held that the reparations must have causal link with the facts of the case, the alleged violations, the proven damages as well as with the measures requested to repair the resulting damages. Therefore, the court must observe such coincidence in order to adjudge and declare according to law. The Article 31(2) indeed refers to a prejudice ... resulting from an internationally wrongful act by a state. In Beneficiaries of Late Norbert and Others v. Burkina Faso (ACHPR, 2011), the court observed that according to International Law, both material and moral damages have to be repaired. Material damage is one that affects economic or material interest that is interest which can immediately be assessed in monetary terms and moral damage is defined as one that affects the reputation, sentiments or affection of a person. In La Grande case (2001), the International Court of Justice (ICJ) observed that the obligation placed on the responsible State by article 31 is to make 'full reparation'. In the case concerning Reparation for Lost Palestinian Property inside Israel, the duty of states to make reparation for violations of international law was laid out by the International Court of Justice (ICJ) as a general principle of law. The burden of more than 10 million Rohingya refugees upon the society and the economy of Bangladesh is due to the atrocities committed in Rakhaine state and Myanmar is responsible for this situation. According to the maxim propounded by Hogu Grotious (1625) that De Jure Belli ac Pacis meaning 'fault creates the obligation to make good the loss'.

Bangladesh will have to assess the damage in monetary value with the assistance of the Office of the United Nations High Commissioner for Human Rights (UNHCHR), International Committee of the Red Cross (ICRC) and other international organizations working on the issue. Regarding the quantification of reparation, the applicable principle is that of full reparation, commensurate with the prejudice suffered. As it was held in Chorzow Factory case (PCIJ, 1928), that the state responsible of violation needs to make an effort 'to wipe out all the consequences of the illegal act and re-establish the situation which would, in all probability, have existed if that act had not been committed.' In Goiburu and Others v. Paraguay (IACHR, 2006), the African Court of Human Rights held that the reparations consist of measures tending to eliminate the effects of the violation that have been committed. Their nature and amount depend on both the pecuniary and non-pecuniary damage that has been caused. Reparation should not make the victims or their successors either richer or poorer and they should be proportionate to the violations declared in the judgment.

\section{Challenges and the Way out}

In the absence of a pragmatic procedure in International Law, it is very difficult for Bangladesh to realize the loss incurred by it due to the huge inrush of Rohingya. According to Article 36 of Statute of International Court of Justice (ICJ), the ICJ has the jurisdiction to adjudge the existence of any fact which, if established, would constitute a breach of an international obligation and the nature or extent of the reparation to be made for the breach of such international obligation. As Myanmar is liable for its internationally wrongful acts that 
ensues harmful consequences in Bangladesh, so ICJ has the jurisdiction over the present Rohingya crisis to determine the nature and extent of reparation that Myanmar should make to Bangladesh.

A dispute may be placed before International Court of Justice (ICJ) in one of the three ways namely by a special agreement between two states or under a clause in a treaty or by virtue of a unilateral declaration by a state (ICJ Statute, 1945). But neither an agreement nor a treaty exists between Bangladesh and Myanmar under which the dispute may be referred to International Court of Justice (ICJ).There is a good diplomatic relation between these two countries that is evident through the visits of the high officials. What Bangladesh can do is to assess the damage in monetary value with the assistance of Office of the United Nations High Commissioner for Human Rights (UNHCHR), International Committee of the Red Cross (ICRC) and other international organizations working on the issue and raise the claim against Myanmar in different bilateral meetings with Myanmar.There is scope for Bangladesh to create international pressure on Myanmar by raising the issue in different international forums and involving the influential countries so that Myanmar becomes compelled to solemnize a bilateral agreement to refer the issue to International Court of Justice.

\section{Conclusions}

Rohingya refugee crisis is the world's long standing and one of the most complex issues to be addressed immediately. It is evident from the historical analysis that politico-religious apartheid as had been practicing since $18^{\text {th }}$ century by the Burmese authority dominated by the Military and the Buddhist extremists is mainly responsible for such an ever ending problem. As such, the Rohingya refugee problem is a creation of Myanmar, but its aftermath has ensued in Bangladesh for the reasons that Myanmar shares a large land and maritime boundary with Bangladesh and most of the members of Rohingya community are Muslim.

Myanmar must share the burden of more than 10 million Rohingya refugees currently having shelter in Bangladesh. As the earlier discussion reveals, Myanmar is responsible for violation of its international obligations to protect its own people from the atrocities committed by its security forces and the extremist Buddhists, it must make good to the victims as well as Bangladesh which is directly affected. However, due to the reluctant attitude of Myanmar to recognize the crisis, Bangladesh will have to exhaust all possible means to realize the reparation. Bangladesh may create international pressure on Myanmar by raising the issue in different international forums and involving the influential countries so that Myanmar becomes compelled to solemnize a bilateral agreement to refer the issue to International Court of Justice (ICJ).

\section{References}

1. Abrar, C. (2010). Repatriation of Rohingya Refugees. Retrieved from www.burmalibrary.org.

2. ACHPR (2011). Beneficiaries of Late Norbert and Others v. Burkina Faso. Retrieved from http://en.african-court.org/images/Cases/Judgment/Nobert\%20Zongo\%20Judgment-\%20English.pdf.

3. Ahmed, I. (2010). The Plight of the Stateless Rohingyas: Response of the State, Society and the International Community, University Press Limited, Dhaka University. Retrieved from http://www.uplbooks.com/book/plight-stateless-rohingyas-responses-state-society-internationalcommunity.

4. Alam, M. (2018). How the Rohingya crisis is affecting Bangladesh and why it matters, the Washington Post. Retrieved from https://www.washingtonpost.com/news/monkey-cage/wp/2018/02/12/how-therohingya-crisis-is-affecting-bangladesh-and-why-it-matters/.

5. Bhuiyan, Humayun Kabir (2019). UNHCR: Rohingya repatriation process a long haul, the Dhaka Tribune. Retrieved from https://www.dhakatribune.com/bangladesh/rohingya-crisis/2019/03/21/unhcrrohingya-repatriation-process-a-long-haul.

6. Bhuiyan, Humayun Kabir (2019). Rohingya repatriation: Myanmar ignoring deal for 19 months, Dhaka Tribune, retrieved from https://www.dhakatribune.com/bangladesh/rohingya-crisis/2019/08/24/rohingyarepatriation-myanmar-ignoring-deal-for-19-months.

7. BROUK (2014). Myanmar's 1982 Citizenship Law and Rohingya. Retrieved from http://burmacampaign.org.uk/media/Myanmar\%E2\%80\%99s-1982-Citizenship-Law-and-Rohingya.pdf.

8. Brownlie, I. (1998). Principles of Public International Law, 9th ed., London, Oxford. Available at https://global.oup.com/academic/product/brownlies-principles-of-public-international-law9780198737445?cc=us\&lang=en\&. 
9. Brownlie, I. (2002). Basic Documents in International Law, $5^{\text {th }}$ ed. Retrieved from https://trove.nla.gov.au/work/10501705.

10. Brownlie, I.(1983). System of the Law of Nations: State Responsibility, Oxford, Clarendon Press. Retrieved from https://www.cambridge.org/core/journals/american-journal-of-internationallaw/article/system-of-the-law-of-nations-state-responsibility-part-i-by-ian-brownlie-new-yorkclarendon-press-oxford-university-press-1983-pp-xvi-302-index4750/A654331AA21A00C0AF3018DA6586BA22.

11. Centre for Policy Dialogue, (2018). Economic Implications of the Rohingya Crisis for Bangladesh and National Budget FY2019. Retrieved from https://cpd.org.bd.

12. Commentaries, ILC Draft Articles on Responsibility of States for Internationally Wrongful Acts 2001, available at http://legal.un.org/ilc/texts/instruments/english/commentaries/9_6_2001.pdf.

13. Grotius, H. (1625). The Law of War and Peace. Lonung Institute. Retrieved from https://lonang.com/library/reference/grotius-law-war-and-peace/.

14. Haque, E. (2012). Rohingya Refugee Paradox: Casting an Inner Eye. Asian Journal of Research in Social Science and Humanities, 2(12), pages 97-108. Retrieved from http://www.aijsh.org.

15. IACHR (2006). Goiburu and Others v. Paraguay. Retrieved from http://www.corteidh.or.cr/docs/casos/articulos/seriec 153 ing.pdf.

16. IACHR (2008). Ticona Estrada and Others v. Bolivia. Retrieved from http://www.corteidh.or.cr/docs/casos/articulos/seriec_191_ing.pdf.

17. ICJ (1980). United States Diplomatic and Consular Staff in Tehran v. Iran, Judgment. Retrieved from https://www.icj-cij.org/en/case/64.

18. ICJ (1982). La Grande case (Germany v. the United States of America). Retrieved from https://www.icjcij.org/en/case/104.

19. ICJ (1986). Military and Paramilitary Activities in and against Nicaragua (Nicaragua v. United States of America). Retrieved from https://www.icj-cij.org/en/case/70/judgments.

20. ICJ (1997). Gabčíkovo-Nagyamaros Project (Hungary/Slovakia). Retrieved from https://www.icjcij.org/en/case/92.

21. ICJ (2001). Germany $v$. the United States of America. Retrieved from http://www.worldcourts.com/icj/eng/decisions/2001.06.27 lagrand.htm.

22. ICTY (1999). Prosecutor v. Dusko Tadic (Appeal Judgement), IT-94-1-A, ILM, 38(6). Available at https://www.icty.org/en/case/tadic.

23. International Law Commission, Draft Articles on Responsibility of States for Internationally Wrongful Acts, November 2001, Supplement No. 10 (A/56/10), chp.IV.E.1, available at: https://www.refworld.org/docid/3ddb8f804.html.

24. Joint Response Plan for Rohingya Humanitarian Crisis (January-December, 2019). Retrieved from http://reporting.unhcr.org/sites/default/files/2019\%20JRP\%20for\%20Rohingya\%20Humanitarian\%20Cr isis\%20\%28February\%202019\%29.comp_.pdf.

25. Khasawneh, Bisher Hani (2007). An Appraisal of The Right of Return And compensation of Jordanian Nationals of Palestinian Refugee Origin and Jordan's Right, under International Law, to bring claims relating thereto, on their behalf to and against Israel and to seek compensation as a host state in light of The conclusion of the Jordan-Israel Peace Treaty of 1994. Retrieved from http://etheses.lse.ac.uk/2131/1/U613363.pdf.

26. New Mandala (2014). Rohingya and national identities in Burma. Retrieved from https://www.newmandala.org/the-rohingya-and-national-identities-in-burma/.

27. Office of the High Commissioner for Human Rights, (2010). Report of the Special Rapporteur on the situation of human rights in Myanmar. Retrieved from https://www.ohchr.org/EN/.../A-HRC-37-70.docx.

28. PCIJ (1928). Chowrzo Factory Case (Germany vs. Polland). Retrieved from https://www.icjcij.org/files/permanent-court-of-internationaljustice/serie_A/A_09/28_Usine_de_Chorzow_Competence_Arret.pdf.

29. Radio Free Asia, (2010). Who are the Rohingya? Retrieved from https://www.rfa.org/english/multimedia/rohingyaPage 04122010151733.html/RohingyaFactSheet04132010102750.html.

30. Rahman, M. (2009). International Law in a Changing World, Dhaka. University Press Limited.

31. Rahman, Utpala (2010). The Rohingya Refugee: A Security Dilemma for Bangladesh, Journal of Immigrant \& Refugee Studies, 8(2), 233-239, DOI: 10.1080/15562941003792135. 
32. Slim, Field-Marshal Viscount William (2009). Defeat Into Victory: Battling Japan in Burma and India, 1942-1945. London: Pan. ISBN 13: 9780815410225.

33. Smith, M. (1991). Burma: Insurgency and the politics of Ethnicity. London. Zed Books._ISBN: 9781856496605. https://journals.lib.unb.ca/index.php/JCS/article/view/4301/4904

34. Starke, J.G. (1989). Introduction to International Law, Butterworth, $10^{\text {th }}$ ed. ISBN 13: 9780406659552.

35. The Guardian, (2017). Text book Example of Ethnic Cleansing. Retrieved from https://www.theguardian.com/world/2017/sep/11/un-myanmars-treatment-of-rohingya-textbookexample-of-ethnic-cleansing.

36. UN Reports of International Arbitral Awards (1926). L. F. H. Neer and Pauline Neer, (U.S.A.) V. United Mexican States, Vol. 4, available at http://legal.un.org/riaa/cases/vol_IV/60-66.pdf.

37. United Nations Human Rights Council (2018, August). Report of the detailed findings of the Independent International Fact Finding Mission on Myanmar. Retrieved from https://www.ohchr.org/Documents/HRBodies/HRCouncil/FFM-Myanmar/A_HRC_39_CRP.2.pdf. 